\title{
ACKNOWLEDGM ENTS
}

Thanks

TO MY ENTIRE FAMILY, who provide ongoing support in my life; the women in my family who serve as examples: Annabel (mother), Carolyn (sister), Lisa (daughter), and Jessica (first granddaughter), who give me total love and total listening; my dad, who gifted me with my writing cabin, the House of David, and encouraged me to be true to my own voice; my brother David, who insisted that I participate in training with Landmark Education and continuously acknowledges me as I create my vision in the world.

To Schreiner University (the community that supports me; faculty development grants; Mary Ann Parker, the faculty secretary; a semester sabbatical; and a house for the Texas Heritage Music Foundation on campus).

To the John Anson Kittredge Foundation for a grant to support me during the last year of this work; Hal Robinson and his shamanic healing work; Jeanne Slobod, my dear friend and mentor who left us April 28, 
2006, at age eighty-nine; Meredith Fund, named in honor of Jeanne's daughter; Past is Prologue for ongoing training; Landmark Education for training in commitment (Carol Redfield and Bruce Saxton); local music magazines (Hill Country Happenings, M.Y.T.H.) for providing outlets for my monthly column; Brad O'Quinn at the Family Sports Center, who supported my physical well-being; Kristen Jetton (a Schreiner student who served as a work-study in my office and a research assistant on this book); Stephanie Gaines, who became a research assistant in 2005 and helped organize my teaching office; and Tim Wilton and his family, who took added responsibility in the September Living History Weekend as well as the THMF office.

To Debbie Fowler, a Schreiner student who contributed to the office for a year; ALL the women who took time to talk with me; my friends (you know who you are) who listened and listened; club owners who supported the research by allowing me to attend the shows and interview the artists.

Mindy Reed, at The Authors' Assistant in Austin, Texas, has a brilliant editing eye and pulled together these interviews in a way that created a manuscript; Theresa May, senior editor at UT Press, had conversations with me that not only encouraged me but helped give me direction. I know she has a daughter who can sing like Janis Joplin! Roger Wood, author of Blues in Houston (UT Press), sent me a list of women to contact in the Houston area. Steve Davis, Dean of Social Sciences at Kingwood College in Houston, shared his extensive research on Janis Joplin with our Texas Heritage Blues Seminar in 2004.

Harold F. Eggers, Jr., provided a link between me and the women he has worked with: Barbara K, Susie Nelson, and Barb Donovan. He brought these women to my classroom and inspired me to continue with this oral history even as it goes beyond the boundaries of this book.

Brian Hawkins heard me talking about this in the hot tub at our sports center and requested the chance to create a television show for Texas Country Reporter. We went back to Houston and talked with Jewel Brown and Trudy Lynn again, camera running. I was blessed with more resources on the women of Texas: Adam Jeffries Schwartz, writer and world traveler, showed up at my house just in time to give this manuscript a close reading. Larry Gunn, a longtime love with an eye for detail, gave it a read. I'm proud to be part of the Texas music catalogue that UT Press in Austin is putting together for Texas and for the world. 